\title{
Evil Media in Dystopian Fiction
}

\begin{abstract}
Media resistance is a recurring theme in contemporary culture, and comprises familiar concerns that can be used to create speculative and readable stories and plots. The chapter discusses key works of dystopic fiction that have inspired media resistance until today: Huxley's Brave New World (1932), Orwell's Nineteen Eighty-Four (1949) and Bradbury's Fabrenheit 451 (1953). All three novels portray authoritarian societies where the growth of mass media represents a danger to civilization. The screen media (cinema and television) are depicted as particularly bad, whereas print culture and books are depicted as representing hope for humanity.
\end{abstract}

Keywords Orwell · Huxley · Bradbury · Dystopic fiction · Media prophesies

\section{Doomsday with a Capital D}

In Edward Bellamy's futuristic novel Looking Backward, published in 1888 , the protagonist finds himself in the year 2000, where new media entertain and enlighten citizens. The dominant medium in this utopian society is an advanced telephone, which brings music, sermons and lectures to every home (Bellamy 1996). In Bellamy's society, citizens prosper and the media strengthen culture, community and democracy. In contrast, 
there are plenty of utopian narratives - in fiction as well as feature films where the media play a destructive and negative role.

In order to understand media resistance as a pervasive element in our culture, it is worthwhile to move beyond public debates and political campaigns and into the realm of fiction. The prevalence of resistant sentiments in society implies that themes in media resistance also pop up in works of art, and in this book, I specifically discuss dystopic fiction and films (see Ch. 6). Fiction can go further than non-fiction in predicting and imagining the future, and can wrap warnings about destructive media in readable and entertaining plots and storylines. As $\mathrm{McNair}$ points out in his analysis of films featuring media and journalists $(2010,19)$, fictional works contribute to "an ongoing public conversation" and may reinforce public concerns. Depictions of utopian societies, from Thomas Moore's Utopia in the sixteenth century and onwards, have served as frames of references in cultural and political debates, and have inspired policies and manifestos.

The three works selected for discussion in this chapter are among the most influential in the Western literary canon: Aldous Huxley's Brave New World (2006, first published 1932), George Orwell's Nineteen Eighty-Four (2008; first published 1949) and Ray Bradbury's Fabrenheit 451 (2013; first published 1953). The novels, of which the first two are English and the third American, have fascinated countless readers, are translated into many languages, and have been adapted into movies, TV-films, comic books, stage plays and reality shows. Their authors continue to appear on rankings of the most influential English writers of the twentieth century (e.g., the novels occupy first, second and third place on the online list Best dystopian Science fiction books, 2015, see also Baccolini and Moylan $2003,1)$. The novels have been praised for their predictions of major upheavals, from the Nazi and Soviet atrocities, to the post-war consumer boom, to recent incidents of terrorism and surveillance. Often the novels, and especially Nineteen Eighty-Four and Brave New World, are contrasted as representing a "soft" vs. "hard" version of dystopia (see, for example, Atwood 2007; Postman 2005a). Yet all three depict the destruction of civilization, as we know it - these are doomsday narratives with a capital D.

Furthermore, all three novels portray apocalypses where media and communication technology play a decisive role. As such, they are excellent illustrations of the point that media resistance is a cultural resource, providing writers and directors with themes and plots recognizable across the globe. And in the same way as fictional accounts may draw on real 
debates, participants in such debates may draw on dystopic fiction. In addition to their canonical status, these novels, and in particular Orwell's and Huxley's, are discussed here because they have served as specific sources of inspiration in media resistance. As pointed out in the introduction, there are predictions of doom in many media-critical works, and many such works are littered with references to these particular novels (Chs. 4-5). This does not imply that writers subscribe to the visions presented, but these function as a common point of reference and a way to distinguish between arguments. Indeed, as will be noted in later chapters, works of media resistance seem to be more inspired by literary doomsaying than by empirical studies of how media operate (see also Ch. 7).

Although the novels portray fascinating accounts of media not yet invented, the most interesting aspect is not what they say about the future, but about the time when they were written. The novels were produced in the interwar and early post-war period, an era of immense media expansion, and reflect the need among intellectuals to develop some kind of "working notions" to understand media influences (see Sundet 2012 , 14). As Natale and Balbi (2014) argue, "media historians should resist the temptation to validate past media prophecies and instead explore the relationship of these prophecies to the culture of the time in which they were created" (207). The novels are read here as historical sources providing insight into concerns and values at the time (see also Ch. 6 on socio-cultural film studies). Although dystopian narratives visualize and engage with political and cultural debates, the narratives are not "simple reflections of their time or the interests of their audiences; they are deliberate fictional constructs that engages with political and social elements" (Kuhn 1990, 30). Dystopian fiction is located in "a negatively deformed future of our own world" (Baccolini 2003, 115), and uses, in particular, exaggeration as a means of engaging readers and formulate warnings: "If this goes on ..." (Gaiman 2013, xii).

In this particular case, the novels exaggerate concerns about early mass media: serial fiction, cinema, radio and comics (Ch. 2). The novels also speculate extensively on the embryonic medium of television and its potentially negative impact. Read as historically grounded warnings, the novels thematize two major dichotomies recurring in media criticism: between print (good) and screen (bad), and between high culture and mass culture. Beyond that, the novels allude to a variety of criticisms and concerns, which has recurred in media resistance until today. 
In this chapter, I describe the characters and plots in each novel, as well as the imagined mediascape and characters' relationships with media. Then I turn to what is at stake - how do the novels thematize media impact and the undermining of broadly shared values - loss of morality and culture, enlightenment and community, democracy and health? Since these novels are works of fiction, they do not provide recipes for action as to what to do with the detested media, but they do point to some paths of resistance as more promising than others. In the last part I discuss where hope lies, what kind of action in relation to media are depicted as bringing a possible light in the end of the tunnel.

\section{Brave New World: Porn at the "Feelies"}

Brave New World was published in 1932, at the height of public and political concern over mass society and mass culture. The novel is set in a distant future, where inhabitants are basically drowning in pleasure; drugs, scent, games, media, music and pornography. Sex is casual and explicit, children are produced in bottles and true emotions are removed through genetic engineering. In the imagined World State, consumerism is the main religion and citizens substitute the name of industrialist Henry Ford for "Lord" or "Christ"; there is even an alternative bible: "My Life and Work, by Our Ford" (Huxley 2006, 218).

The main male character Bernard Marx is a genetic engineer who is struggling to find his place in society. He starts an affair with the female protagonist Lenina, who is, like other female character in the three novels, portrayed as more superficial than the male characters. The third main figure is John, a "savage" they bring to The World State from an outside reservation; the shortcomings of the state are very much seen through his eyes. John becomes a celebrity, but is deeply disturbed by how modern society has evolved.

The mediascape in Brave New World is a mixture of old, new and imagined media. Radio, television, films, music and games are everywhere and constantly used; they represent - in combination with drugs and sex the main ingredients of a good life. Huxley's novel depicts "synthetic music boxes," "scent organs," electric "skysigns," and electronic games, such as "Electromagnetic Golf." Lenina, who represents a devout media consumer, is exited to tell John about the immense media pleasures

awaiting him in the World State: the "lovely music that came out of a box," "all the nice games you could play," "the pictures that you could 
hear and feel and smell," as well as "the boxes where you could see and hear what was happening at the other side of the world" (128). As the story evolves, Lenina's character continue to represent the sentiments that 1930's media critics warned about. While the male character of Bernard yearns for strong emotions and true passion, the character of Lenina uses media to block out silences as well as conversation: "Let's turn on the radio. Quick!," she says when conversation gets serious, reaching for "the dialling knob on the dashboard" and turning it "at random" (90).

Television, which hardly existed when Brave New World was written, is everywhere in the World State. Although some programmes (news, sport) are described, television is very much "flow": "Television was left on, a running tap, from morning till night" (198), and a character constantly watching television is described as "on holiday in some other world" (155). While television prompts passivity, cinema has evolved into virtual reality. The most spectacular media innovation in the novel is the "feelies," huge cinema palaces where image, scent and tactile effects together create an interactive effect. As imagined media, the "feelies" go far beyond the "talkies" (sound movies) of the 1920s and 1930s; feely-characters are described as "more solid-looking than they would have seemed in actual flesh and blood, far more real than reality" (168), synthetic music and scent is pumped out to accentuate the effect, and spectators experience the same sensations as characters by pressing on knobs. When the characters on the screen kiss, the audience can feel the effect:

\footnotetext{
"Aa-aah." "Ooh-ah! Ooh-ah!" the stereoscopic lips came together again, and once more the facial erogenous zones of the six thousand spectators in the Alhambra tingled with almost intolerable galvanic pleasure. "Ooh...." (168)
}

With their interactive features, the futurist media in Brave New World are spectacular innovations, their exaggerated features reflecting the criticism of early popular media (Ch. 2). Media keep the population distracted with mindless entertainment, their role similar to drugs, which are also widely available. To indicate the hugely important role played by media in this future society, the production facilities for television, cinema, radio and music are described as enormous: "At Brentford the Television Corporation's factory was like a small town" (62). "The buildings of the Hounslow Feely Studio covered seven and a half hectares" (62). "Then came the Bureau of propaganda by Television, 
by Feeling picture, and by Synthetic Voice and Music respectively twenty-two floors of them" (66).

There is also a Department of Writing, but reading is not encouraged; indeed, state institutions use loud noises and electroshock to condition infants to hate books and flowers. All books published before A.F. 150 [A.F $=$ After Ford $]$ have been forbidden (5l), as reading comes in the way of consumption and pleasure seeking: "You can't consume much if you sit still and read books" (50). While popular media were criticized as "trash" in the 1930s, Huxley turns the tables and portrays a society where literature is "smut." As Mustapha Mond, a state controller, explains,

Our civilization has chosen machinery and medicine and happiness. That's why I have to keep these books locked up in the safe. They're smut. (234)

Propaganda and conditioning are crucial to achieve stability, and inhabitants are genetically modified to make them "like their unescapable social destiny" (16). Media are used for brainwashing; from a very young age, children are subject to "sleep-teaching" or "hypnopaedia"; machines repeating the same phrases all night. Adults are indoctrinated through public loudspeakers; when a riot break out the police calms the population with "Synthetic Anti-Riot Speech Number Two (Medium Strength)" (214). The ideas of enlightenment and uplift have vanished; instead, culture and information are streamlined to fit people of different conditioning. Not only the screen media are innovative; newspapers for the lower classes are described as being printed "on khaki paper and in words exclusively of one syllable" (66). Film plots for "feelies" are described as pornographic and stereotypical. Lenina takes John to see a feely where a woman is kidnapped by a "black madman" for "a wildly anti-social tête-àtête," and later becomes the mistress of all her three rescuers. While Lenina, whose character is conditioned to like this kind of stuff, finds the film "lovely," John the Savage, who has received his education from discarded volumes of Shakespeare in a reservation outside The World State, finds the plot "horrible," "base" and "ignoble." Frustrated, he goes home and reads Othello (171).

The media keep the population distracted, but media are also shown to be violent and cruel in their dealings with vulnerable individuals. The portrayal of John's demise is telling; he is first exploited as a celebrity and then victimized by documentary makers and journalists. The book ends with a chilling scene where a fleeing John is hunted down by a pack of 
reporters, described as "turkey buzzards settling on a corpse" (248). John is basically treated like an animal by the media, we are told that he is put under surveillance by "the Feely Corporation's most expert game photographer," and the documentary about him could be "seen, heard and felt in every first-class feely-palace in Western Europe" (254). After a media witch hunt that turns into an orgy, John hangs himself and the story ends.

\section{Nineteen Eightr-Four: Dictatorship by Telescreen}

Published in 1949, deeply marked by the atrocities of World War II, Nineteen Eighty-four portrays a world that is more squalid, grey and poor. The events unfold in Airstrip One, formerly known as London, in a world that has been divided into three great super-states constantly at war, reflecting the post-war arms race. The ruling Party, called Ingsoc, with its leader Big Brother, is in full control of society, and has even invented a new language called Newspeak to shape and manipulate the way people think. Thoughtcrime - thinking rebellious thoughts - is the worst of all crimes. Rather than communal bonds, society is held together by hate; the novel depicts media-rich ceremonies organized to stimulate the hating of real and imagined enemies.

The main character Winston works in the Ministry of Truth; his job is to alter historical records to fit the needs of the Party. He is described as increasingly dissatisfied and initiates an illicit affair with a co-worker, Julia, who is more of a happy-go-lucky character than the brooding Winston. Julia and Winston hide in a safe room in the proletarian quarters and begin plotting against the regime, but it turns out that they have been under surveillance the whole time, and they are subsequently captured and tortured.

The media in Nineteen Eighty-four are pluralistic, powerful and ubiquitous. All the media of the 1940s are present: radio, film, newspapers and popular fiction, all with exaggerated negative features and depicted as serving the aims of the state. However, what truly makes the story frightening is the imagined medium of the telescreen - an advanced form of two-way television very unlike the early post-war television service that had just started up in Britain when the novel was written (Briggs 1985). The first time the telescreen is introduced is in a scene in Winston's apartment, it is described as "an oblong metal plaque like a dulled mirror which formed part of the surface of the right-hand wall" $(2006,4)$. We soon learn that screens are everywhere, all party members have them, you find 
them in all public places, and there are also hidden screens. The telescreen is described as incredible versatile and interactive, it is a television, a surveillance device, a loudspeaker, and a telephone. The screen is "delicate enough to pick up heartbeat" (82) and a "single flicker of the eyes" (39). We are informed that Winston is constantly aware of its presence, seen in phrases such as these: "Winston kept his back turned to the telescreen. It was safer, though, as he well knew, even a back can be revealing" (5). There is no way of knowing when the Thought Police plugs into your individual wire:

You had to live - did live, from habit that became instinct - in the assumption that every sound you made was overheard, and, except in darkness, every movement scrutinized (5).

The dramatic effect of the constant presence of the telescreen is that of living in a laboratory, a type of experience later recreated in the reality show Big Brother from 1999 (see Ytreberg 2003) and also in the film The Truman Show (Ch. 6). This is media portrayal at its most dystopic, echoing and pre-echoing concerns about surveillance technologies throughout media history. But the telescreen is not just evil in the way it is used for surveillance, the description of its effects also allude to criticism of media escapism and media as interruption devices. The constant noise from the telescreen makes it impossible to concentrate; a constant outpouring of "facts" about ongoing wars and the victories, military music and patriotic songs, a barrage of statistics proving the success of the Party. Winston's attempts as reflection are constantly disturbed; "with the voice from the telescreen nagging at his ears he could not follow his train of thought further" (107).

Also in Nineteen Eighty-Four the media headquarters are impressive, signifying enormous media power. The Ministry of Truth is responsible for all cultural, educational and media production, and completely dwarfs its surroundings: It is "an enormous pyramidal structure of glittering white concrete, soaring up, terrace after terrace, three hundred meters into the air" (2006, 5-6), with 3000 rooms above and same below ground. The task of the Ministry is to supply the citizens of Oceania with "every conceivable kind of information, instruction or entertainment" (44). The culture bears the hallmark of the 1940s popular culture, but taken one-step further, there are "rubbishy newspapers containing almost nothing except sport, crime and astrology, sensationalist five cents novelettes, films oozing with sex," as 
well as "sentimental songs" produced mechanically on a machine known as a "versificator" (46).

Books are supressed, modified or simply noted as absent. In Winston's flat there is a "shallow alcove" which "had probably been intended to hold bookshelves" (6), but all books printed before 1960 have been destroyed. Short version of classical works by authors such as Chaucer, Shakespeare, Milton and Byron are available in Newspeak, and there is also new fiction, but like the songs, novels are also produced mechanically on novel-writing machines. Alluding to the criticism of standardized mass culture, we are told that "[b]ooks were just a commodity that had to be produced, like jam or bootlaces" (136). Pornography is produced for proletarian youth, with titles such as "Spanking Stories" and "One night in a Girls School," but also these are completely standardized: "They only have six plots but they swap them around a bit" (137).

All forms of creativity are discouraged. Winston is portrayed as taking a great risk by obtaining a notebook, an offence punishable by death or forced-labour camp. The novel details how censorship and propaganda are vital to the stability of the regime. Tellingly, Winston's job is to falsify newspapers such as The Times in order to support the current "truth," and the process of alteration is applied to all genres - books, periodicals, pamphlets, posters, leaflets, films, sound-tracks, cartoons, photographs "to every kind of literature or documentation which might conceivably hold any political or ideological significance" (42).

Meticulous and bureaucratic forms of censorship are combined with violent and brutal media indoctrination. In addition to the annual celebration of "Hate week," a festival centred on enjoyment of hateful media products, gruesome killings of civilians are served up as entertainment in cinema films. Reflecting the atrocities of authoritarian regimes, such as the public trials in Stalinist Soviet in the 1930s, traitors are paraded on television, forced to testify their alleged crimes, live on camera.

\section{FAHrenheIt 451: Burning All Books}

Published in 1953, only five years after Orwell's dystopia, Fabrenheit 451 is set in a completely different world. Across the Atlantic, the novel reflects the beginning of the 1950s consumer boom where all sorts of goods became available to the American public: cars, refrigerators, washing machines and not least television sets. However, goods do not bring happiness to characters; life in Fabrenheit 451 is sterile and cold. There is 
clearly too much stimulation for a meaningful and healthy life: drinking alcohol, smoking incessantly, driving very fast, consuming media, glaring at huge advertising posters. Suicides are frequent, but victims are quickly back on their feet after being cleaned up by a form of medical vacuum cleaner. In this society, the fire brigade is important for upholding social stability, as their purpose is to locate and burn all books (Fahrenheit 451 is purportedly the temperature at which paper burn).

The main character Guy Montag is a firefighter increasingly at odds with the ethics of his profession. Montag is married to Mildred, another female character represented as a superficial individual; like Lenina in Brave New World, she is a passionate media consumer. Montag's journey from loyal book-burner to ardent rebel is stimulated by characters he meets on his way, a young girl named Clarisse, whose innocent questioning opens Montag's eyes to the emptiness of his life, and Faber, a retired English teacher, whose character informs Montag of all that has been lost under the current regime. The story ends with the city being bombed to pieces while Montag flees to join a rebel group, "the book lovers," living on abandoned railway tracks, a post-industrial site of the kind that is often preferred in dystopic fiction.

In Fabrenheit 451, reading books is "against the law" (5), and the job of the fire brigade is to hunt down books and burn them. In another ironic inversion of the public criticism in the early and mid-1900s, the aim is also here to obliterate literary culture; the fire station has a list of a million forbidden books and the only permitted books are cartoons and books with pictures. People are killed and taken away to asylum if they do not give up their books; in a crucial scene, an old woman refuses to leave her books and is burned along with them when the firemen arrive. Montag's character is transformed by this event, as he begins to wonder whether there really might be something worthwhile in the books he burns for a living. He begins to steal and hide books, and endangers the life of his wife and acquaintances when he pulls one out and reads when they have company.

While books are burnt, television viewing is encouraged. The novel reflects the criticism of early commercial television in the 1950s, the screen described as "lit with orange and yellow confetti and skyrockets and women in gold-mesh dresses and men in black velvet pulling one-hundred pound rabbits from silver hats" (67). Despite the low-quality content, television is seen as having a strong and direct influence on viewers, as Montag notes: 
[Y]ou can't argue with the four-wall televisor. Why? The televisor is "real." It is immediate, it has dimension. It tells you what to think and blasts it in. It must be right. It seems so right. It rushes you on so quickly to its own conclusions your mind hasn't time to protest, What nonsense! (80)

One reason why television is so influential is sheer size. In Fabrenheit 451, Bradbury has added innovative features to the nascent television medium of the 1950s; television is described as "parlor walls"; each screen covering an entire wall in the living room. In Montag's home, we are told that the screens already cover three walls, and although screens are expensive, Mildred's character is nagging him to replace also the fourth wall with a screen. She is presented as deeply bored with real life and argues: "If we had a fourth wall, why it'd be just like the room wasn't ours at all, but a kind of exotic people's rooms" (18). The "parlor walls" are interactive; in one passage Mildred is talking to the television announcer, in another she is depicted as playing a part in an interactive drama. We are told that she has won a competition and received her lines by mail:

"They write the script with one part missing. It's a new idea. The home-
maker, that's me, is the missing part. When it comes time for the missing
lines, they all look at me out of three walls and I say the lines. Here, for
instance, the man says, 'What do you think of this whole idea, Helen?' And
he looks at me sitting here center stage, see? And I say, I say -" She paused
and ran her finger under a line on the script. "I think that's fine!" (17-18)

The interactivity alludes to concern over loss of community and family bonds, as Mildred refers to people on television as family members: uncles, aunts, nephews, nieces. When not watching television, Mildred is presented as wearing "seashell radio" (with tiny earplugs, not yet invented when the book was written), which she keeps on all night to block out other impulses. Montag speculates whether he will have to buy himself a radio station to be able to communicate with her, referring to the recurring theme of media as an isolating force. Mildred is portrayed as callous and not even willing to turn off television when Montag is sick: she claims that her favourite show is on, but cannot name it; it is all noise and flow. Montag despises her as well as the television "walls"; he represents the view that television is just "a great thunderstorm of sound," described as turning on a (mental) washing machine (42). 
The authoritarian society depicted in Fahrenheit 451 differs from the World State and Airstrip One; in this society it is not state propaganda that keeps people in the dark. Instead, the novel marks a shift to the post-war era with its explosion in mass culture; everything is made bland to suit the mass market, and there is nothing that can offend minorities or sensitive individuals. Quality culture is dying, instead there are comics and "threedimensional sex magazines" (55). All plots have been condensed to suit popular taste, in a direct reference to the public debate, Hamlet is described as "a one-page digest in a book that claimed 'now at last you can read all the classics; keep up with your neighbors" (53). The effect is complete uniformity; the character of Clarisse sums it up when she tells Montag "they all say the same things and nobody says anything different from anyone else" (28).

Yet, the media regime in Fabrenheit 451 is also depicted as murderous and brutal when the social order is threatened. When Montag flees towards the end of the novel, he is followed by television cameras and media helicopters in a wild chase, not unlike the media frenzy in Brave New World. Montag escapes to join a resistance movement, but the state, as well as the television show covering the manhunt, need "a snap ending." So instead of Montag, an innocent victim is caught and killed live on camera, as a brutal form of entertainment. Again, media people are portrayed as literally walking across dead bodies to get what they want.

\section{What is at Stake? Print vs. Screen, Good vs. Bad Literacy}

The novels are immensely rich, and could be discussed in the light of almost any aspect of modernity. Yet, the novels portray an unusually large variety of mediascapes, and the media depicted, separately and together, provide comments and reflections on major issues in media resistance. The three novels in their various ways thematize how the media endanger key values of morality, culture, enlightenment, democracy, community and health. Indeed, the media situation in Huxley's World State, Orwell's Airstrip One and Bradbury's sterile city can be seen as exaggerated illustrations as to what could happen if the warnings in media resistance are not heeded and changes not reversed. In this sense, the novels fit the description of dystopia as "a conservative genre": "Its function is to warn readers of the possible outcomes of our present world and entails an extrapolation of key features of contemporary society" (Baccolini 2003, 115). 
The explicit sex in Brave New World, and the widespread availability of pornography in all three novels, illustrates the concern that media undermine morality; there are pornographic "feelies" at mainstream theatres (Brave New World), three-dimensional sex magazines (Fabrenheit 451) and standardized pornography plots for proletarian youth (Nineteen Eighty-Four). The concern for culture is abundantly illustrated; culture is produced industrially on innovations such as "versificators" and "novelwriting machines" (Nineteen Eighty-Four) and commercialization has increased with advertising devices such as "skysigns" (Brave New World). Surveillance technology and propaganda have replaced democracy, and state terror, mass culture, genetic engineering or endless consumption has eroded community bonds. In Fabrenheit 451, front porches are removed because no one sits and talks at night; in Brave New World children are produced in factories and in Nineteen Eighty-Four children are spying on their parents on behalf of the state. Media noise block out or prevent communication, concentration and all forms of learning and enlightenment, people hide from each other with "seashell radio" to be listened to with tiny earplugs (Fabrenheit 451), or prefer escapist entertainment such as "Electromagnetic Golf" (Brave New World).

In addition to illustrate how media erode broadly shared values, the portrayal of media in these novels reflects explicitly on two major dichotomies prevalent in media resistance at the time: between print (good) and screen (bad), and between authentic (high) culture and mass (low) culture.

Although there are many innovations, the most spectacularly dystopic media in the three novels are the screen media. These are definitely a step up from the screen media available in 1932, 1949 and 1953 respectively when the novels were published. All three novels include dystopic visions of the cinema (a place for vulgar and violent entertainment), and indulge in speculating about the effects of the emerging medium of television. In order to depict negative effects, screens are grossly enlarged and exaggerated, there are big screens, small screens and screens everywhere, and the screen media are versatile and powerful. The "feelies" described in Brave New World are virtual reality media where all senses are stimulated, the telescreens in Nineteen Eighty-Four and "parlor walls" in Fabrenheit 451 are imagined forms of convergent media with a multitude of functions that make them invasive and disturbing. The good guys in the novels, particularly John the Savage, Winston and Montag, all detest the screen media and try to avoid them, whereas the characters portrayed as more 
superficial, Lenina and Mildred, enjoy them, reflecting the idea that women were more vulnerable to influence from popular culture (Ch. 2).

In contrast to the fantasies about screen media, the imaginations about traditional forms of literacy in the three novels - poetry, prose, verse, as well as academic books - are of obsolescence and death (see also Natale and Balbi 2014). The novel powerfully illustrates how concerns in media resistance are not just about the presumably bad effects of new media, but about warnings that more valuable media may become extinct. The three authors fantasize spectacularly about the bad things that can happen to books and literacy, such as babies being conditioned with electroshocks to hate books and discarded copies of Shakespeare eaten by mice (Brave New World), apartments where bookshelves are replaced with screens and classical works re-written in Newspeak (Nineteen Eighty-Four), and the burning of books and persecution of book-lovers (Fabrenheit 451). The warning in all three stories is that reading, writing and printing is the very marker of a civilized life, and if books lose ground, the path to apocalypse is short.

As pointed out in Chapter 2, books and printing have also been subject to resistance; the novel was considered "vulgar" when it first appeared (Williams $1958,306)$. The three novels innovatively reflect on the criticism of vulgar mass culture and what may happen if warnings such as those advocated by F. R. Leavis and Horkheimer and Adorno are not listened to in their manifestos from 1930 and 1944 respectively. Instead of classical literature, the media that were strongly criticized in the 1930s, 1940s and 1950s have flourished and expanded, and high culture is shown to be destroyed. The two latter novels, Nineteen Eighty-Four and Fabrenheit 451, also describe comics and abbreviated books, forms that where defended with the argument that they would spread literary knowledge and enhance reading skills. However, both were widely criticized for producing a tepid middle culture destroying the original classics as well as popular taste (see, for example, Wertham 2004, 121; MacDonald 2011, 35).

All three novels refer in various ways to Shakespeare and other classics as a counterpart to the lower forms of media and culture. Brave New World has borrowed its title from the Shakespeare play The Tempest, John the Savage is self-educated from discarded volumes of Shakespeare, and the novel is littered with Shakespearian references. The two other novels also use the destruction of Shakespearean works as an indication of the rot in society: In Nineteen Eighty-Four Shakespeare is rewritten and transformed in Newspeak and in Fabrenheit 451 Hamlet is reduced to a "one-page digest" $(2013,53)$. Culture exists, but only for dummies! 


\section{The Obliteration of Civilization}

The novels reflect on distinctions between print and screen and between good and bad literacy, but go further; they also speculate about the death of entire civilizations. The books portray fully fledged versions of the mass societies critics warned about in the interwar period; there is authoritarian rule instead of democracy, excess and escapism instead of enlightenment, thrash instead of culture, consumerism instead of community, dehumanization instead of morality, and destruction of mental and physical health.

How has this happened? Like other dystopian texts, the novels can be read as warnings but also as explanations: as texts connecting the dots and explaining how societies have ended up in a very bad state. As Baccolini $(2003,115)$ points out, the dystopian narrative has a complex relationship to history; it often appears as a "critique of history" because it is portraying a deformed future, but history and memory are also crucial to plots. In many dystopian narratives, rulers fear the power of history and keep it hidden from the public since history and memory are "dangerous elements that can give the dystopian citizen a potential instrument of resistance." In all three novels, the main character at some point discovers the "history" of society, or more specifically, how civilization has been obliterated to be replaced by awful dictatorships. The emergence of mass media is crucial in all three explanations.

In Brave New World, the role of State controller Mustapha Mond is to explain the emergence of the World State. In the beginning, he claims, there were such things as democracy, liberalism, family life, Christianity and individuality, but after war, destruction and economic collapse everything changed. There was brutal and conscious persecution of dissidents, such as "the gassing of culture fans in the British Museum" $(2008,50)$, but it was also realized that "you couldn't do things by force" (49). Together with genetic engineering, the mass media did the trick, providing both the tools for propaganda and the distraction that tempted people into pleasure seeking and consumption. When the masses seized political power, happiness rather than truth and beauty mattered:

You've got to choose between happiness and what people used to call high art. We've sacrificed the high art. We have the feelies and the scent organ instead (220).

In Nineteen Eighty-Four, the history of society is partly revealed in a secret manifesto $(2006,191)$, and this account also points to the combination of 
brutal repression and mass media propaganda. Continuous warfare was the party's means to uphold scarcity and inequality, but the active obliteration of memory, falsification of truth, narrowing of language and media fakery was also crucial. The account describes the present dictatorship as different from all previous dictatorships; in the past, it was difficult to keep citizens under control, but this changed with new media:

The invention of print, however, made it easier to manipulate public opinion, and the film and the radio carried the process further. With the development of television, and the technical advance which made it easier to receive and transmit simultaneously on the same instrument, private life came to an end (214).

From this moment, the manifesto says, it was not only possible to enforce "complete obedience to the Will of the State," but also "complete uniformity of opinions on all subjects" (214).

In Fabrenheit 451, the history is pieced together through information from Beatty, the Fire Chief, and filled out by Faber, the former English professor whom Montag tracks down. Also in this society, war and destruction played a part, but most important for the evolvement of authoritarianism was the lowering of standards spearheaded by the mass media: "Films and radios, magazines, books levelled down to a sort of paste pudding norm" (5l). The sensibilities of various minorities helped to curb free speech. It was a long history of decay, but not the fault of the state:

It didn't come from the Government down. There was no dictum, no declaration, no censorship, to start with, no! Technology, mass exploitation, and minority presence carried the trick, thank God. Today, thanks to them, you can stay happy all the time, you are allowed to read comics, the good old confessions, or trade journals (55).

Although the details vary, all three authors describe mass communications as vital mechanisms in creating authoritarian societies, not necessarily causes, but instruments in the hands of the evil rulers. But they go further; the growth of the mass media is paralleled by a decline in vital institutions of civil society and the failure of intellectuals to protect the values of enlightenment, democracy and culture. 
Specifically, the expansion of media parallels a forceful decline in science and the humanities: Scientists are exiled (Brave New World), there is no word for science in Newspeak (Nineteen Eighty-Four) and in Fabrenheit 451 we are told that "the last liberal arts college shut down for lack of students and patronage" forty years earlier (71). History is meticulously and actively falsified, dropped from the curriculum and ridiculed: in Brave New World society is run according to the Henry Ford's dictum: "History is Bunk!" Language fare no better, most world languages are dead (Brave New World), English and spelling are ignored (Fahrenheit 451), and in Nineteen EightyFour, the whole of the English language, Oldspeak, is destroyed. In all three novels, intellectuals are depicted as critical, but not sufficiently vigilant when warning signs were flashing, and many academics have sold out to the regimes; brilliant scientists work with genetic manipulation in Brave New World and philologists are busy creating Newspeak in Nineteen Eighty-Four. In Fabrenheit 451, teachers have completely succumbed to media and education consists of "TV-class" or "film teacher" (27).

Indeed, in all three novels there has been a transfer from classical disciplines to media and communication disciplines and professions. The main characters all work in what may broadly be labelled "the media," although in a perverted sense: In Brave New World Bernard Marx is accredited as "the Professor of Feelies in the College of Emotional Engineering" (156), in Nineteen Eighty-Four, Winston is falsifying newspapers, and Montag in Fahrenheit 451 burns books. Those who work with media are not to be trusted, and part of the liberation process is to get out of this kind of work.

\section{What to Do? Where Does Hope Lie?}

While cultural and political manifestos are about mobilizing for action, no such explicit demands can be claimed of fiction. Yet, it is interesting to see if the authors point to a way out. Having created these awful dystopias, do Huxley, Orwell and Bradbury allow the reader any hope? What kind of action is pointed to as potentially leading humanity to a better place and what kind of hope is envisaged for characters?

In all three stories, there are parallel narratives of repression and resistance. A counter-narrative is developed "as the dystopian citizen moves from apparent contentment into an experience of alienation and resistance" (Baccolini and Moylan 2003, 5). The re-appropriation of language, memory, history and forms of education lost or prohibited are crucial tools 
in the protagonists' actions to instigate social change. Yet, the actions are not always successful in terms of leading in a new direction.

The bleakest story is Nineteen Eighty-Four. Winston hopes that the proletarians will revolt $(2006,274)$, but the destiny of the main characters, who are tortured, brainwashed and coerced to love Big Brother, indicates that Winston's thought are probably feeble fantasies. The only hope lies in the possibility that autonomous subjects may continue to emerge, despite the appalling conditions (Ytreberg 2003).

The two other novels are more hopeful. Both in Brave New World and in Fabrenheit 451, enclaves on the margins of society are described with remnants of traditional civilization. In Brave New World there is the savage reservation where they still have some books and breed children the natural way, as well as the islands where writers and scientists are exiled. Hope lie in the character of Helmholz, a friend of Bernard's, who is sent to the Falklands; he embraces the idea of being sent to a cold place, since this will give him the best opportunities to write. Helmholz is portrayed as desperately sick of writing state-approved propaganda rhymes; he wants to write "piercingly" (70); he is inspired by Shakespeare, which John the Savage has taught him. The controller Mustafa Mond, who is himself an intellectual who has sold out to the regime, describes exile very positively to Helmholz; the islands are where they send "the most interesting people":

All the people who aren't satisfied with orthodoxy, who've got independent ideas of their own. Every one, in a word, who's any one. I almost envy you, Mr. Watson (227).

In Fabrenbeit 451, hope is in the "book people," an illicit group living on abandoned railway tracks, each memorizing a classical work to conserve heritage and knowledge. Many are former academics; ironically one of the first Montag meets is Dr. Simmon's from UCCL, "a specialist in Ortega Y'Gasset" (143), the mass society theorist who predicted in 1930 that the masses would destroy everything of quality (Ch. 2) The book people are the closest one can come to fictional heroes from the humanities. They think of people as "book jackets" and their hopes are timeless and cogently expressed (146-147):

And when the war's over some day, some year, the books can be written again, the people will be called in, one by one, to recite what they know and 
we'll set it up in type until another Dark Age, when we might have to do the whole damn thing over again. But that's the wonderful thing about man; he never gets so discouraged or disgusted that he gives up doing it all over again, because he knows very well it is important and worth the doing.

Fittingly, it is by removing oneself from the authoritarian state and the mass media, and seeking refuge in traditional literacy and writing, that humanity is offered a glimmer of hope. And in Fabrenheit 451, we actually come close to a "happy ending." In the last passages, society is obliterated in a great blast, and when the novel ends, it looks like only the book people have survived.

Open Access This chapter is licensed under the terms of the Creative Commons Attribution 4.0 International License (http://creativecommons.org/licenses/ by $/ 4.0 /$ ), which permits use, sharing, adaptation, distribution and reproduction in any medium or format, as long as you give appropriate credit to the original author(s) and the source, provide a link to the Creative Commons license and indicate if changes were made.

The images or other third party material in this chapter are included in the book's Creative Commons license, unless indicated otherwise in a credit line to the material. If material is not included in the book's Creative Commons license and your intended use is not permitted by statutory regulation or exceeds the permitted use, you will need to obtain permission directly from the copyright holder.

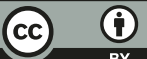

